\title{
Adapting Risk Management for Profit and Loss Sharing Financing of Islamic Banks*
}

\author{
Irawan Febianto \\ Faculty of Economics and Business, University of Padjadjaran, Bandung, Indonesia \\ Email: i_febianto@yahoo.com, irawan.febianto@fe.unpad.ac.id
}

Received October 9, 2011; revised November 25, 2011; accepted December 22, 2011

\begin{abstract}
The low level of participation of the Islamic banks in profit and loss sharing (mudharabah and musharakah) financing models has become one of the problems in the development of the industry. These arrangements are unique to Islamic banking and account for its superiority over conventional banking on grounds of ethics and efficiency, but the majority of Islamic banks have limited themselves to less risky trade-financing assets, that tend to be a shorter maturity. This paper intends to analyzes why Islamic banks are reluctant to indulge in mudharabah and musharakah financing. Finally, it explores the risk management concept that might solve the problems.
\end{abstract}

Keywords: Islamic Banks; Profit and Loss Sharing Arrangements; Risk Management

\section{Introduction}

The concept of Islamic banking is essentially based on the idea that Islam prohibits riba, but permits trade and profitloss sharing arrangements. The two forms of profit and loss sharing, which is frequently mentioned in fiqh literature, are mudharabah and musharakah. These equitybased products are unique to Islamic banking and in some sense, account for its superiority over conventional banking on grounds of ethics and efficiency.

Specialists attempting to find an alternative to interestbased finance build up their hopes on Islamic banks to provide a significant amount of profit-sharing (PLS) financing. They called them the primary Islamic modes of finance and considered the rest as secondary modes. Primary modes would have economic effects similar to direct investment and produce a strong economic development impact. Theoreticians have provided some arguments in favor of profit-sharing financing over fixed return-on-capital financing. However, in practice, profitsharing finance has remained negligible in operations of Islamic banks [1].

The objective of this paper is to discuss why Islamic banks tend to avoid profit and loss sharing arrangements and how the risk management concept can offer solutions for this problem.

\footnotetext{
"Earlier version of this paper has been written with sis. Rahmatina Kasri from Universitas Indonesia and presented at the $2^{\text {nd }}$ Islamic Economics Conference 2007 (iECONS 2007), Kuala Lumpur: Faculty of Economics and Muamalat, Islamic Science University of Malaysia.
}

\section{Literature Review}

A financial system is usually defined as a set of rules and regulations governing and controlling the flow of funds from the surplus spending units (SSU) to the spending deficit unit (SDU) [2]. The household, business, and government sectors are part of both the SSUs and SDUs.

An Islamic financial system, by definition, provides a linkage between SSUs and SDUs through an array of financial products and services that do not violate the norms of Islamic ethics [3]. Islamic scholars have not only established the basic principles and norms, but also identified the contractual mechanisms that conform to these norms and do not violate them in any manner [3].

As part of the financial system, the basic principle of Islamic banking is the sharing of profit and loss and the prohibition of riba' (interest). Amongst the common Islamic concepts used in Islamic banking are profit sharing (Mudharabah), safekeeping (Wadiah), joint venture (Musharakah), cost plus sale (Murabahah), and leasing (Ijarah).

The two forms of profit and loss sharing modes of financing, which find frequent mentions in fiqh literature, are Mudharabah and Musharakah. In Musharakah, the bank's profit on the loan is equal to a certain percentage of the partner's profits. Once the principal amount of the loan is repaid, the profit-sharing arrangement is concluded. Furthermore, Mudharabah is venture capital funding of an entrepreneur who provides labor while financing is provided by the bank so that both profit and risk are shared. Such participatory arrangements between 
capital and labor reflect the Islamic view that the borrower must not bear all the risk/cost of a failure, resulting in a balanced distribution of income and not allowing the lender to monopolize the economy.

Musharakah is a relationship established under a contract by the mutual consent of the parties for sharing of profits and losses in the joint business. It is an agreement under which the Islamic bank provides funds, which are mixed with the funds of the business enterprise, and others. All providers of capital are entitled to participate in management, but not necessarily required to do so. The profit is distributed among the partners in pre-agreed ratios, while the loss is borne by each partner strictly in proportion to respective capital contributions. This concept is distinct from fixed-income investing (i.e. issuance of loans) [4].

Mudharabah is an arrangement or agreement between a capital provider and an entrepreneur, whereby the entrepreneur can mobilize funds for its business activity. The entrepreneur provides expertise and management and is referred to as the Mudarib. Any profits made will be shared between the capital provider and the entrepreneur according to an agreed ratio, where both parties share in profits and only capital provider bears all the losses if occurred [4].

Due to greater complexities arising from the nature of specific risks and the profit and loss sharing concept of Islamic financing (Musyarakah and Mudharabah), an Islamic bank faces greater difficulties in recognizing and handling risks compared with a conventional bank [5].

Islamic Banks are reluctant to indulge in profit and loss sharing instruments for several reasons [6]:

1) Their inherent riskiness and the banks' low appetite for risk;

2) The additional monitoring costs associated with such instruments;

3) The lack of transparency in markets within which Islamic banks are operating;

4) The reluctance of the banks' depositors to take risks. This factor could be a reflection of the low level of transparency in the banking system, which leads to a low level of trust between investors/depositors and the banks. Consequently, this will lead to the reluctance of depositors to take long-term and risky positions with banks. The result is that the depositors tend to be risk averse, and therefore the banks become risk averse. Although they may have good investment opportunities on the basis of profit and loss sharing, they may not be able to find depositors who are willing to take the risk;

5) There are very few credible institutional infrastructures to conduct common monitoring and to share information of credit rating on borrowers \& entrepreneurs; this is known as informational asymmetry.

The ability of banks to monitor their borrowers conduct and credit worthiness depends greatly on the extent

of information available. Some information is not made accessible to bankers, while others are. This uneven distribution of information or known as informational asymmetry sometimes leads banks into making poor credit decisions resulting in large non-performing loans. In cases where banks have inside information, they are in a better position to choose financial instruments with better riskreturn features. This provides them with greater opportunities to give better returns to their depositors [7,8].

Iqbal (2005) has also noted some of the reasons why Islamic banks tend to avoid the profit and loss sharing arrangements. He uses the two side considerations, demand side and supply side, to explain about the perspective of Banks as Rabb al-Mal (capital provider) and entrepreneur as Mudarib (expertise and management provider) regarding PLS (profit and loss sharing contracts) (See Table 1).

\section{Methodology}

The present study by nature is library research. Content analysis is the key tool which we intend to use to extract necessary information materials. From the findings, we will provide some recommendation for the improvement of profit and loss sharing arrangements practiced in Islamic banks. The sources of information include Islamic Financial Services Board (IFSB) report in 2005. Any necessary information for the study will be extracted using

Table 1. Demand and supply considerations of PLS contract.

\begin{tabular}{cc}
\hline DEMAND-SIDE & SUPPLY-SIDE \\
CONSIDERATIONS & CONSIDERATIONS \\
\hline
\end{tabular}

PLS requires keeping and revealing detailed records. Most businessmen do not like this.

It is difficult to expand a business financed through Mudharabah because of limited opportunities to re-invest retained earnings and/or raising additional funds.

The entrepreneur cannot become the sole owner of the project except through diminishing $\mathrm{Mu}-$ sharakah, which may take a long time

Adaptation from: Iqbal, Munawar. (2007). A Guide to Islamic Finance London: Risk Books.

Due to moral hazards and adverse selection programs in all agentprinciple contracts, there is a need for closer monitoring of the project. This requires project monitoring staff and mechanisms, which increases the costs of these contracts.

On the liabilities side, the structure of deposits in Islamic banks is not sufficiently long term. Therefore, they do not want to get involved in long term projects.

PLS contracts require a lot of information about the entrepreneurial abilities of the customer. This may not be readily available to the bank. 
descriptive method, and then will be critically analyzed and interpreted using explanatory method.

\section{Discussion and Findings}

\subsection{Risk Management for Profit and Loss Sharing Arrangements ${ }^{1}$}

The nature of risks in Islamic Banking is not the same as with the nature of risk in conventional banking. The Mudharabah contract is the cornerstone of financial intermediation and thus of banking in Islamic banking. The basic concept is that both mobilization funds and utilization funds are on the same basis of profit sharing among the depositors, the bank, and the entrepreneur. However, in practice, the funds are mainly applied by means of commodities and asset financing instruments that avoid interest but are not profit sharing, such as murabahah, salam, istisna, and ijarah [6].

Below we discuss some of the risk management concept for profit and loss sharing arrangements, based on the Islamic Financial Services Board (IFSB) report in 2005 [9].

\subsubsection{Credit Risk}

Credit risk is generally defined as the potential that the counterparty fails to meet its obligations in accordance with agreed terms.

Islamic bank may hold the role of Mudarib and Musharakah partner and in that situation there is a risk of a counterparty's failure to meet their obligations in terms of receiving deferred payment and making or taking delivery of an asset. A failure could relate to a delay or default in payment. The invested capital in a Mudharabah or Musharakah contract will be transformed to debt in case of proven negligence or misconduct of the Mudarib or the Musharakah's managing partner. In case of default, IIFS are prohibited from imposing any penalty except in the case of deliberate procrastination. In the latter case, IIFS are prohibited from using the amount of the penalty for their own benefit; they must donate any such amount to charity.

Islamic bank should involve in identification, measurement, monitoring, reporting and control of credit risks. Adequate capital should be held against credit risks assumed. IIFS shall also comply with relevant rules, regulations and prudential conditions applicable to their financing activities.

1) IIFS may use holistic approach to assess credit risk and ensure that credit risk management forms a part of an integrated approach to the management of all financial procedures.

2) IIFS may establish policies and procedures defining

\footnotetext{
${ }^{1}$ The Author acknowledges Sis. Huma Ayub (Pakistan) and Bro. Ghulam Rabbani Mansoori (Afghanistan), the authors' colleagues from Management Centre of International Islamic University Malaysia, for parts of this section.
}

eligible counterparties, the nature of approved financings and types of appropriate financing instruments.

3) The IIFS shall obtain sufficient information to permit a comprehensive assessment of the risk profile of the counterparty prior to the financing being granted.

4) IIFS shall carry out a due diligence process in evaluating counterparties, in particular, for transactions involving:

- New ventures with multiple financing modes;

- In the case of Mudhārabah financings, additional counterparty reviews and evaluations will focus on the business purpose, operational capability, enforcement and economic substance of the proposed project including the assessment of realistic forecasts of estimated future cash flows.

5) IIFS shall engage appropriate experts including a Shari'ah advisor or Shari'ah Board to review and ensure that new, ad-hoc financing proposals or amendments to existing contracts are Shari'ah-compliant at all times.

6) The IIFS may also engage an appropriate technical expert (for example an engineer) to evaluate the feasibility of a proposed new project and to assess and approve progress billings to be made under the contract.

7) IIFS shall establish limits on the degree of reliance and the enforceability of collaterals and guarantees. They shall protect themselves against legal impediments that may restrict the accessibility of collaterals when they need to enforce their rights in respect of a debt. IIFS shall formally agree with the counterparty at the time of signing the contract on the usage, redemption and utilization of collaterals if the counterparty defaults in payment.

8) IIFS shall have appropriate credit management systems and administrative procedures in place to undertake early remedial action in the case of financial distress of counterparty or, in particular, for managing problem credits, potential and defaulting counterparties. This system will be reviewed on a regular basis. Remedial actions will include both administrative and financial measures.

Administrative measures may inter alia include:

- Negotiating and following-up pro-actively with the counterparty through maintaining frequent contact with the counterparty;

- Setting an allowable timeframe for payment or to offer debt-rescheduling or restructuring arrangements (without an increase in the amount of the debt);

- Resorting to legal action, including the attachment of any credit balance belongs to defaulters according to the agreement between them; and

- Making a claim under Islamic insurance.

Financial measures include, among others:

- Imposing penalties to be donated to charity in accordance with the Shari'ah rule;

- Establishing the enforceability of collaterals or third party guarantees. 
9) IIFS shall set appropriate measures for early settlements, which are permissible under their Shari'ah rules and principles for each Islamic financing instrument. Some customers may expect a discount, which the IIFS can give of their own volition as a commercial decision made on a case-by-case basis. Alternatively, irrespective of industry practice the IIFS can grant a rebate, at their discretion (not to be mentioned in the contract), to their customers by reducing the amount of the debt in subsequent transactions.

10) IIFS shall ensure that there is sufficient Islamic insurance coverage of the value of the assets, subject to availability. If necessary, the IIFS shall engage an insurance advisor at an early stage to review the insurance coverage of the leased assets.

\subsubsection{Equity Investment Risk}

Equity investment risk can be defined as the risk arising from entering into a partnership for the purpose of undertaking or participating in a particular financing or general business activity as described in the contract, and in which the provider of finance shares in the business risk [9].

The characteristics of such equity investment include considerations as to the quality of the partner, underlying business activities and ongoing operational matters. In Musharakah and Mudharabah contract, the risk profiles of potential partners (Mudarib or Musharakah partner) are crucial considerations for evaluating the risk of an investment to undertake of due diligence. Due diligence is part of IIFS fiduciary responsibilities as an investor of IAH funds on a profit-sharing and loss-bearing basis (Mudharabah) or a profit and loss sharing basis (Musharakah). The risk profiles include the past record of the management team and quality of the business plan, and human resources involved in the business activity.

Factors relating to the legal and regulatory environment (including policies pertaining to tariffs, quotas, taxation or subsidies and any sudden policy changes) affecting the quality and viability of an investment, and need to be considered in the risk evaluation.

There is also the risk attaching to a lack of reliable information as a base to IIFS's investment appraisals, such as an adequate financial control system. The mitigation of these risks may require the investor to take an active role in monitoring the investment, or the use of specific mitigating structures.

IIFS should also be prepared for delays and variations in cash flows patterns and possible difficulties in executing a successful exit strategy, although timely allocation of profit can be agreed upfront. The risks that come from using of profit sharing instruments for the purpose of financing do not include credit risk in the conventional sense, but share a crucial characteristic of credit risk be- cause of the risk of capital impairment.

IIFS shall have in place appropriate strategies, risk management and reporting processes in respect of the risk characteristics of equity investments, including Mudharabah and Musharakah [9]. They should ensure that their valuation methodologies are appropriate and consistent, and shall assess the potential impacts of their methods on profit calculations and allocations. The methods shall be mutually agreed between the IIFS and the Mudarib and/ or Musharakah partners. IIFS should also define and establish the exit strategies in respect of their equity investment activities, including extension and redemption conditions for Mudharabah and Musharakah investments, subject to the approval of the institution's Shari'ah Board [9].

How to mitigate Equity Investment Risk:

1) IIFS shall define and set the objectives of, and criteria for, investments using profit sharing instruments, including the types of investment, tolerance for risk, expected returns and desired holding periods;

2) IIFS shall have, and keep it review from time to time, policies, procedures, and suitable management structures. They should ensure that proper infrastructure and capacity are in place, including evaluation of Shari'ah compliance, periodical meetings with partners and proper record meetings;

3) IIFS shall identify and monitor the transformation of risks at various stages of investment lifecycles. Because different stages may give to different risks. IIFS shall use Shari'ah compliant risk-mitigating techniques, including the use of Shari'ah permissible security from the partner;

4) IIFS shall have independent parties where necessary to give audits and valuations of the investments;

5) IIFS shall establish the criteria for exit strategies, including the redemption of equity investments and the divestiture of under performed investments. The criteria may include alternative exit routes and the timing of exit. In case of losses where improved business prospects exist, IIFS may indicate an investment extension period. IIFS shall agree with the investment partner the methods for the treatment of retained profits by the investee.

\subsubsection{Market Risk}

In general, market risk can be defined as the risks that influence the value of a large number of assets or the systematic and unsystematic risks originating in instruments and assets traded in well-defined markets that cause their price volatility [10]. Specifically, for Islamic financial institution IFSB [9] defines market risk as the risk that arises from fluctuations in values in tradable, marketable or leaseable assets ${ }^{2}$ and in off-balance sheet individual portfolios ${ }^{3}$.

\footnotetext{
${ }^{2}$ Including sukuk.

${ }^{3}$ According to AAOIFI standard the off-balance sheet accounts record entries for restricted investment account (Mudharabah Muqayyada).
} 
Market risk can be classified into four categories namely benchmark rate risk, foreign exchange rates risk, equity prices risk and commodity prices risk. As their names suggest, they are adverse price movement on the value of assets mentioned above with respect to changes in benchmark rate (such as LIBOR rate), foreign exchange rate, equity prices, and commodity prices respectively.

In the context of Musharakah and Mudharabah, different products under those financial structures entitle to different type of market risk. However, benchmark rate risk appears almost in all of the products and thus can be regarded as one of the most influential market risk and discussed in detail in the paper. Musharakah-based Letter of Credit for example entitle mostly to benchmark rate risk, exchange rate risk, and commodity prices risk. Whereas housing finance under Musharakah Mutanaqisah might be more exposed to benchmark rate risk.

As previously mentioned, different financial products have different market risk profile and hence individual evaluation needs to be done. However, as general guide for risk management IFSB has stated that Islamic financial institution shall have in place an appropriate framework and reporting for market risk management by taking into account the contractual agreement with the fund provider and supported by adequate capital. The strategy should be reviewed and communicated periodically to related parties.

Furthermore, a sound and comprehensive market risk management process and information system should include:

- A conceptual framework to assist in identifying underlying market risks for each specific product and able to quantify it;

- Guidelines governing risk taking activities in different portfolios of restricted IAH and their market risk limits;

- Appropriate frameworks for pricing, valuation and income recognition;

- A strong MIS for controlling, monitoring and reporting market risk exposure and performance to appropriate levels of senior management.

The regulation above implies that banks should have, in the first place, benchmark risk management systems that assess the effect of its changes on earning and economic value of the assets. The measurement system should be able to utilize generally accepted financial concepts and risk management techniques to assess all risk associated with a bank's assets, liabilities, and off-balance sheet position. Some of the techniques for measuring a bank's benchmark rate risk exposure are GAP analysis $^{4}$, duration analysis ${ }^{5}$, and simulation analysis ${ }^{6}$ under different market scenarios [11,12]. Survey conducted by Khan and Ahmed [10] reveals that only around 30\% of Islamic financial institutions used market risk mitigation technique (simulation analysis) in their institutions.

In addition to that, banks should also disclose their assets valuation method in all situations. This is important especially because of the nature of mudharabah and musharakah that permit withdrawal of investor's money/ assets at any time and thus cancel the project financing. In the valuation of assets where no direct market prices are available, banks shall incorporate a detailed approach in their own product program to value their market risk positions and appropriate forecasting techniques to assess the assets value can be used. However, where available valuation methodologies are deficient (for example, private equity investments), banks shall assess the need to:

- Allocate funds to cover risks resulting from illiquidity, new assets and uncertainty in assumptions underlying valuation and realization;

- Establish a contractual agreement with the counterparty specifying the methods to be used in valuing the assets.

\subsubsection{Liquidity Risk}

Liquidity risk is risk arises due to insufficient liquidity that reduces bank's ability to meet its liabilities when it falls due. Specifically, IFSB defines it as potential loss to Islamic financial institution arising from their inability either to meet their obligations or to fund increases in assets as they fall due without incurring unacceptable costs or losses.

Liquidity risk appears in both Mudharabah and $\mathrm{Mu}$ sharakah financial products. In restricted Mudharabah investment accounts for example, a sound repayment capacity is required because fund providers have the right to withdraw their funds at any time. Another example can be seen from Musharakah financing where bank must be able to provide the committed funds as well as paying the expenses of the partnership or profit to the counterparty. Hence, liquidity risk management is important for these financing products.

As standard guidelines for liquidity risk, IFSB encourages an Islamic financial institution to have in place a liquidity management framework and appropriate system

\footnotetext{
${ }^{4} \mathrm{GAP}$ analysis is a benchmark (interest) rate risk management tool based on the balance sheet. The analysis focuses on the potential variability of net-interest income over specific time intervals. In this method a maturity re-pricing schedule that distributes interest-sensitive assets, liabilities, and off-balance sheet positions into time bands according to their maturity (if fixed rate) or time remaining to their next re-pricing (if floating rate) is prepared. These schedules are then used to generate indicators of interest rate sensitivity of both earnings and economic value to changing interest rates.

${ }^{5}$ Duration model is derived by taking into consideration all individual cash inflows and outflows. Duration is value and time weighted measure of maturity of all cash flows and represents the average time needed to recover the invested funds.

${ }^{6}$ Also known as sensitivity analysis, for example with respect to the return/yield of the assets.
} 
to measure and monitor liquidity exposures for each category of unrestricted and restricted investment account. The risk management must take into consideration the nature of the Islamic financial institution, their business activities, and their capital market environment. It is suggested that the liquidity management policies should cover:

- Strategy for managing liquidity involving effective BOD and senior management oversight.

- A framework for developing and implementing sound processes for measuring and monitoring liquidity.

- Adequate systems in place for periodic monitoring and reporting liquidity exposures.

- Adequate funding capacity, with particular reference to the willingness and ability of shareholders to provide additional capital when necessary.

- Liquidity crisis management (example: fixed asset realization and sale/leaseback arrangements).

The policies mentioned above should also incorporate quantitative factors (such as funding and investing portfolio diversifications and availability of standby lines of external funding) as well as qualitative factors (such as management capability, treasury management and public relation, management information system and reputation of IIFS). Both factors are important predominantly because failure to manage liquidity would not only harm the banks financial position but also their reputation.

Once the liquidity management framework is established, an appropriate system to measure and monitor liquidity exposures must be constructed. Several guidelines provided by IFSB are as follows:

- Identify any future shortfalls in liquidity by constructing maturity ladders based on appropriate time bands. For example, possible future shortfall is higher with unlimited-period Musharakah compared to diminishing Musharakah because the latter involves a known cash flow;

- Calculate net funding requirement (NFR) by considering internal assessment expectations and incentives for the investment account holder;

- Establish periodical cash flow analysis under various market scenarios;

- Establish the maximum amount of cumulative liquidity mismatches, such as maximum provision (allowance) of bad debts.

Other than controlling mechanism explained above, there are several liquidity risk mitigation tools commonly practiced by the banking system. In the context of Mudharabah and Musharakah, there are at least two major tools to mitigate the risk. First, the bank should control the liquidity position of its funds. This is important because the essence of liquidity management problem arises from the fact that there is a trade-off between liquidity and profitability and mismatch between demand and supply of liquidity assets. Thus, while the bank has no con- trol over the source of funds, it can control the use of funds and given priority to its liquidity position. Given the opportunity cost of liquid funds, the bank should make all profitable investment after having the reserve for sufficient liquidity. In other words, management must clearly define their attitude towards liquidity management.

As one consequence of the first point, the IIFS should assess the necessity and extent of their access to available funding sources. Some possible funding sources are natural cash flow from banking activities (for example in case of Musharaka Mutanaqisah), the realization of tradable invested assets, assets securitization, and capacity to access shareholder's funds.

Finally, it should have a liquidity contingency plan addressing various stages of a liquidity crisis, for example when withdrawal does not follow normal patterns, followed by orderly manner to liquidate the assets or investment. For this purpose, a standard measure is the liquidity gap for each maturity bucket and in each currency (if the transactions involve other than domestic currency). Another common measure is the share of liquid assets to total assets or to liquid liabilities. While the availability of core deposits (such as Mudharabah investment account) which are rolled over, and not volatile, provides a significant cushion for most Islamic banks, the remaining volatile deposits cannot be readily matched with short-term liquid assets, other than cash and other low-yielding assets.

\subsubsection{Rate of Return Risk}

Rate of Return Risk is an overall balance sheet exposure where mismatches find between assets and balances from fund providers (Sahib ul mal). It is the bank's responsibility to manage the Sahib ul mal's expectations and the liabilities to current account holders.

An increase in benchmark rates may result in Investment Account Holders (IAH or Sahib ul mal) having high expectations of rate of return. It differs from interest rate risk because the Bank is concerned to result of the investment activities at the end of the investment period. It is not pre determined exactly.

The Bank is under market pressure to pay a return more than the rate that has been earned on assets financed by IAH (Sahib ul mal), when return on assets are compared with competitors rates. So the Bank decides to give up its right to part or the entire Mudarib share of profits to satisfy, retain the fund providers and discourage them from withdrawing their funds.

There are some factors that Banks should consider in rate of return risk:

1) Displaced commercial risk derives from competitive pressures on Bank to attract and retain investors (fund providers). The decision of the Bank to give up 
their rights to a part of or their entire Mudarib share in profits in favor of IAH (fund provider) is a commercial decision. It needs to be clear and well defined policies and procedures with approval of Bank's BOD.

2) A Profit Equalization Reserve (PER), is the amount set by Bank out of the gross income, before it goes to Mudarib share, to maintain a certain level of return on investment for IAH(fund providers) and increase owners' equity. The computing amounts will be set by approval of Bank's BOD.

3) An Investment Risk Reserve (IRR) is the amount that will be set by Bank out of income of IAH (fund providers), after allocating the Mudarib share to reduce the effects of the risk in the future investment losses on IAH (fund providers). The terms and conditions IRR can be set by the BOD and should get approval of IAH (fund provider).

The Bank is responsible to ensure that the management processes relating to the identification, measurement, monitoring, reporting and control of the rate of return risk are in place. The Bank should be aware of the factors that give rise to rate of return risk. In general, profit rates earned on assets reflect the benchmark of the previous period and do not match immediately to changes in increased benchmark rates. No returns are expected by current account holders because they suddenly can withdraw their funds.

The Bank should make a policy and framework for managing the expectations of their shareholders and IAH (fund providers). If the market rates of returns of competitors' IAH are higher than Islamic Bank's IAH (fund providers), the Bank should evaluate the nature and level of the expectations of the IAH (fund providers) and assess the amount of the gap between competitors' rates and the own IAH's expected rates.

\subsubsection{Operational Risk}

Operational Risks arises from failures of Islamic banks in internal controls involving processes, people and systems and from external events. In addition to these, Islamic banks are also exposed to risk relating to Shari'ah compliance and fiduciary responsibilities [13]. The operational risks expose Islamic banks to:

- fund providers' withdrawals;

- loss of income;

- voiding of contracts.

All of these lead to diminished reputation and the limitation of business opportunities.

For Musharakah and Mudharabah financial products compliant with Shari'ah rules and principles is of great importance. If the products are not acting in accordance with the Shari'ah rules and principles, transactions shall be nullified and any income earned from them shall not be recognized as profit.
How to mitigate Operational Risk:

1) Islamic bank should develop a comprehensive and sound frame work for developing and implementing a prudent control environment for the management of operational risk;

2) Islamic banks should opt for Periodic Reviews to deduct and address operational deficiencies. This might include independent audit coverage and assessment by internal and/or external auditors;

3) Islamic bank should have in place adequate systems and controls to ensure compliance with Shari'ah. This means that Shari'ah compliance considerations are taken into account whenever the bank accept deposits and investment funds, provide finance and carry out investment service for their customers;

4) Islamic contract documentation should comply with Shari'ah rules and principles - with regard to formation, termination and elements possibly affecting contract performance such as fraud, misrepresentation, duress or any other rights and obligations;

5) Shari'ah compliance review at least annually, performed either by a separate Shari'ah control department or as part of the existing internal and external audit function;

6) In case of restricted Investment Account Holders (IAH) Islamic banks should maintain a separate account to ensure proper maintenance of records for all transactions in investment;

7) To offset future short fall in rate of return for IAH in case of recurring losses, Islamic bank may set up separate reserves according to the accounts classes or risks. The method for setting up and using reserves should be documented to include the basis for determining the transfers in and out of reserves, maximum thresholds for specific reserves and the use of and closure of specific reserve;

8) In any case where a separate fully owned subsidiary or special purpose vehicle is set up by IIFS as a means to undertake specific investments or financing in particular Musharakah the Islamic bank should ensure that the risk arising in the subsidiary and/or special purpose vehicle are monitored and reported at the group level (risk management on a consolidated basis). An investment loss arising in a subsidiary or special purpose vehicle may give rise to reputation risk for the Islamic bank.

\section{Conclusions}

Islam is not only a religion but also a complete way of life that consists of not only rituals but also politics, economy and social system. It provides guidance for our life that can give benefits not only to the Muslim society but also for the society in general [14]. One of the benefits that the society can gain is through Islamic economics [15], especially Islamic financial and banking system. 
The Islamic law of contracts offers a rich variety of contracts, including profit and loss sharing arrangements through Mudharabah and Musharakah contracts. These contracts are unique, and in some sense offer Islamic banking superiority over conventional banking on grounds of ethics and efficiency. Arguably, because of their riskiness and uniqueness, in practices it less popular among Islamic banks, especially on their asset side. While on the liability side Islamic banks practices Mudharabah or $\mathrm{Mu}-$ sharakah contracts, on the asset side they prefer practices Murabahah contracts (fixed-income modes of financing and installment sale). These deviations have led to increase riskiness at the institutional and systemic level.

The role of risk management concept especially in $\mathrm{Mu}-$ dharabah and Musharakah provides solutions to this problem. It can give Islamic bank guidance of how to manage the risk attributed to profit and loss sharing arrangements through Mudharabah and Musharakah contracts. Hopefully this guidance can motivate or encourage Islamic banks to be more participative in profit and loss sharing arrangements, especially on their asset side.

The discussion of this paper is still limited in the concept of the risk management for Mudharabah and $\mathrm{Mu}-$ sharakah contracts. A further empirical research of the concept, especially the implementation of the actual practice is highly recommended to support the findings.

\section{REFERENCES}

[1] M. Iqbal, "A Guide to Islamic Finance," Risk Books, London, 2007.

[2] S. A. Rosly, "Critical Issues on Islamic Banking and Financial Markets,” Dinamas, Kuala Lumpur, 2005.

[3] M. Obaidullah, "Islamic Financial Services," Islamic Economics Research Center, King Abdul Azis University, Jeddah, 2005.

[4] M. T. Usmani, "An Introduction to Islamic Finance,"
Idara Isha'at-E-Diniyat (P) Ltd., New Delhi, 2005.

[5] V. Sundararajan and L. Errico, "Islamic Financial Institutions and Products in the Global Financial System: Key Issues in Risk Management and Challenges Ahead," IMF Working Paper WP/02/192, Washington DC, 2002.

[6] H. V. Greuning and Z. Iqbal, "Banking and the Risk Environment," In: S. Archer and R. A. A. Karim, Ed., Islamic Finance: Regulatory Challenge, John Wiley and Sons, Singapore, 2007, pp. 11-39.

[7] INCEIF, "CIFP Part 1 Study Material, Islamic Economics and Finance: Theory and Ethics," INCEIF, Kuala Lumpur, 2006.

[8] INCEIF, “CIFP Part 1 Study Material, Deposit Mobilisation and Financing Management," INCEIF, Kuala Lumpur, 2006.

[9] Islamic Financial Services Board, "Exposure Draft No.1: Guiding Principles of Risk Management for Institutions (Other Than Insurance Institutions) Offering Only Islamic Financial Services,” IFSB, Kuala Lumpur, 2005.

[10] T. Khan and H. Ahmed, "Risk Management: An Analysis of Issues in Islamic Financial Industry," IDB/IRTI Publisher, Jeddah, 2001.

[11] E. Banks and R. Dunn, Richard. "Practical Risk Management: An Executive Guide to Avoiding Surprises and Losses," John Wiley \& Sons, West Sussex, 2003.

[12] C. L. Culp, "The Risk Management Process," John Wiley \& Sons, Hoboken, 2001.

[13] V. Sundararajan, "Risk Characteristics of Islamic Products: Implications for Risk Measurement and Supervision," In: S. Archer and R. A. A. Karim, Ed., Islamic Finance: Regulatory Challenge, John Wiley and Son, Singapore, 2007, pp. 40-68.

[14] M. Ariff, "Economics and Ethics in Islam, Readings in the Concept and Methodology of Islamic Economics," CERT Publication, Kuala Lumpur, 2005.

[15] M. U. Chapra, "Objectives of the Islamic Economic Order, an Introduction to Islamic Economics and Finance," CERT Publication, Kuala Lumpur, 2005. 